Review

\title{
The Suitability of Mozambican Cashew Nuts to be Protected Under Geographical Indications
}

\author{
Edgar Cambaza ${ }^{1,2, *}$ \\ 1 Laboratory of Agricultural and Food Process Engineering, Graduate School of Agriculture, Hokkaido \\ University, Japan; edy@bpe.agr.hokudai.ac.jp \\ 2 Department of Biological Sciences, Faculty of Science, Eduardo Mondlane University, Mozambique; \\ edycambaza@yahoo.com.br \\ * Correspondence: accademus@protonmail.com; Tel.: +8180-2876-1106
}

\begin{abstract}
The protection of Geographical Indications (GIs) is part of the intellectual property (IP) rights described in the Agreement on Trade Related Aspects of Intellectual Property Rights (TRIPS) after the Uruguay Round (1986-1994). The members of the World Trade Organisation (WTO), including Mozambique, have adopted it. This country legislated GI under Decree 18/99 (04/05/1999, title II, chapter VI) of the national Industrial Property Code, harmonised with TRIPS. However, there is little information about its enforcement and impact in the industry. This review analyses the possibility of protecting the Mozambican cashew nuts industry under the GI act. The industry, with major participation of smallholders and employing mostly women, produces one of the most profitable export commodities, though it has suffered colossal losses over the last thirty-five years. The analysis has shown that it is suitable and probably advantageous to protect the cashew nuts under the Decree 18/99. On the other hand, other local trade policies from 1991 are negatively impacting the entire industry and these might create the illusion of inefficacy of the new IP rights including the protection of GIs.
\end{abstract}

Keywords: intellectual property, geographic indication, cashew nuts, Mozambique

\section{Introduction}

The Agreement on Trade Related Aspects of Intellectual Property Rights (TRIPS) launched the framework for the protection of geographic indications (GIs) in the section 3 (WTO 1994). The there is no universal consensus about what should be defined as GIs (Blakeney 2012) but TRIPS defines them as "indications which identify a good as originating in the territory of a Member, or a region or locality in that territory, where a given quality, reputation or other characteristic of the good is essentially attributable to its geographical origin".

These indications provide to particular geographic areas the exclusivity to use their names in local goods through designation or presentation so that no foreign external entity can take unfair advantage of their reputation (IPpro 2008). Although it is a useful tool to developing countries, the entire process to establish a consistent infrastructure to manage its enforcement has been challenging in several countries including Mozambique (USAID 2009). Indeed, Evans and Blakeney (2006) mentioned a lack of a consistent "solution to global harmonisation of GIs". Thus, the problem is not just within the countries but also between them.

The concern about the most effective strategies to enforce the protection of GI justifies the Workshop on Geographical Indications in Kampala (Uganda) between the European Commission and the African Union Commission (European Commission 2012). In this meeting, several potential GIs in Africa were listed but Mozambican product was mentioned, though the list has shown specific GI regulation for that country (African Union Commission and European Commission 2011).

In the Conference of Kampala, some case studies were presented. For example, Gichovi (2011) described the Kenyan experience with coffee and Andreas (2011) spoke about the vanilla from Madagascar. Several other case studies of potential GIs in Africa were published by Blakeney et al. 
(2012). Regarding Mozambique, the country still lacks documented and analysed evidences of potential GIs and this is particular important because otherwise the entire effort for police making shown in several official documents (Conselho de Ministros 1999, 2007, Soeiro, Grade, and de Deus 2008, USAID 2009) will be worthless.

Mozambique had economic improvements but most people remain below the poverty line and agriculture employs the majority of the workforce (USAID 2009, UNDP 2010). According to USAID (2009), the implementation of regulations for geographical indications "could contribute substantially to the value of Mozambique's agricultural products by creating consumer demand, adding value, and permitting premium rather than commodities pricing".

Kanji, Vijfhuizen, Artur, et al. (2004) identified cashew as an important source of income, employment and nutrition in Mozambican rural areas, where about one million households (40\% of the total population) have access to cashew trees. They also say that mainly women process most cashews at home. Regarding the fact that "geographical indications protect the reputation of goods based on their qualities, characteristics, or reputation arising from their geographical origin" (USAID 2009), are the Mozambican cashew nuts suitable to benefit from such protection?

So far, intellectual property seems to be a poorly explored matter in Mozambican academic circles (USAID 2009). Most information comprises regulation, plans and strategies (Conselho de Ministros 1999, 2007, USAID 2009), few authors describe the outcomes of such strategies (USAID 2009) and apparently there is no accessible information suitability of the new policies for the local industries. The current analysis aims to respond to such gap in knowledge focusing on the Mozambican cashew nuts industry. It will also give a glance on other potential GIs, particularly the Guruè tea and the prawns from Banco de Sofala.

\section{A glance at Mozambique}

\subsection{Natural and sociodemographic features}

The Republic of Mozambique (Figure 1) is a South-eastern African country bordering Mozambique Channel with a coastline of 2,470 km (CIA 2013, INTIC 2006). The geographic coordinates are 18'15" S and 35' 00" E (CIA 2013). The country is surrounded by Tanzania (north), Malawi and Zambia (northwest), Zimbabwe (west), Swaziland (south) and South Africa (southeast) (INTIC 2006). The total area is $799,380 \mathrm{~km}^{2}$, being $786,380 \mathrm{~km}^{2}$ of land and $13,000 \mathrm{~km}^{2}$ of water (CIA 2013). The climate is tropical and subtropical humid (INTIC 2006, CIA 2013) and it has fertile soils, especially in the northern mountainous areas near the Zambeze river (Encyclopædia Britannica 2013).

The total population is estimated to 23.9 million people (World Bank 2013). According to UNICEF (2003) and (CIDA 2013), about 69\% live in rural areas. The main ethnic groups are African $(99,66 \%)$, Europeans (0,06\%), Euro-Africans (0,2\%) and Indians (0,08\%) (CIA 2013). This mixture resulted from influence of Asian traders and Portuguese long history of colonialism till 1975 (Encyclopædia Britannica 2013). 


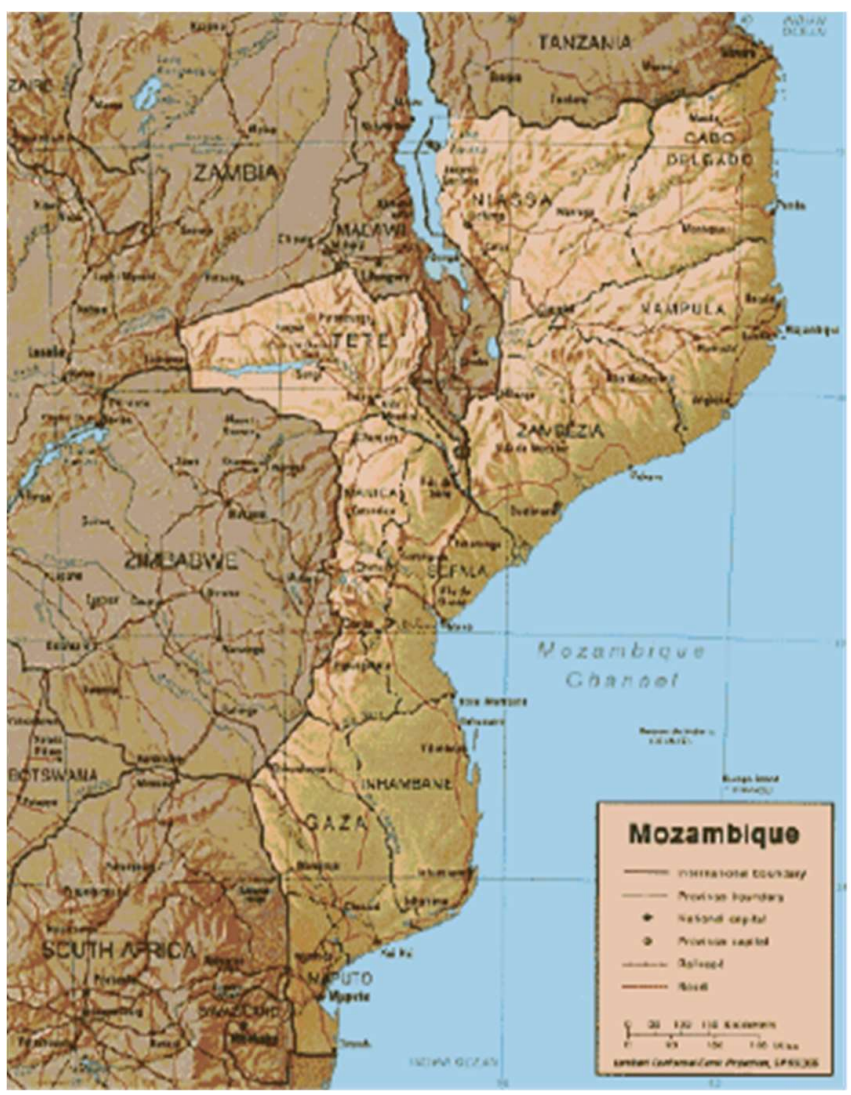

Figure 1. Mozambique. Source: Welch (2003).

\subsection{Economy}

Though it had one of the African highest annual economic growth rates $(6.8-7.6 \%)$ in the last decade, a civil war (1977-1992), natural calamities among other issues are the reasons why the country still depends on $40 \%$ of foreign assistance for its annual budget (CIA 2013, World Bank 2013, Bertelsmann Stiftung 2012). The GDP is 12.9 billion US dollars and it comes from agriculture (29.8\%), industry (23\%) and services (47\%) (World Bank 2013, EPAU 2012).

The main exports are cashew products (US\$ 21 million), prawn (US\$ 42 million) and manufactures (US\$ 34 million) (World Bank 2013, EPAU 2012) but there are other commodities such as aluminium, electricity, tobacco, sugar, cotton and timber (EPAU 2012, USAID 2009). The main export partners are Netherlands (36.9\%), South Africa (14.6\%), Portugal (3.4\%) and China $(2.5 \%)$ (EPAU 2012). The local cashew industry used to be the World leader, with $35-40 \%$ international market share but it had a downsizing basically because of inefficiencies during a major economic reform (McMillan, Rodrik, and Welch 2002, World Bank 2006). Yet, Große-Rüschkamp and Seelige (2010) reported a growth from 0.5 to 3.25 million tonnes from middle 1980s to 2007.

\section{The Mozambican cashew industry}

\subsection{Industry profile}

The Mozambican cashew nuts are mostly produced by smallholder farmers (95\%) and 16 "new generation" factories (World Bank 2006, Kanji, Vijfhuizen, Artur, et al. 2004) assisted by some organisations (INCAJU, AICAJU and ACA) and 10-30\% is sold in the informal market (GroßeRüschkamp and Seelige 2010, MEDA 2011). The factories process 13,750 tons and employ nearly 3,000 workers, most on a seasonal basis (World Bank 2006). The nuts from the southern provinces are 
exported by vendors to South Africa and the ones from the northern area (the "Cashew Triangle", Figure 2) are exclusively exported by the Dutch company Global Trading \& Agency BV to the European market (MEDA 2011).

The current landscape of the current Mozambican cashew nuts industry was shaped by drought, war and displacement, aging and diseased trees and inconsistent policies towards the smallholder sector after the liberalization of domestic cashew marketing in 1991-92 (McMillan, Rodrik, and Welch 2002, Kanji, Vijfhuizen, Braga, et al. 2004). The Government replaced an export ban on raw cashews by a quota and a tax, replaced fixed prices by a system of minimum prices, privatised the most influent organisation and factories of the sector and eliminated the control over prices of processed products (World Bank 2006). This process favoured the export of raw cashews and reduction of Mozambique's bargaining power towards India (the leading buyer of raw cashews) (World Bank 2006, McMillan, Rodrik, and Welch 2002). The industry collapsed and $90 \%$ of the workforce became unemployed (World Bank 2006). According to the World Bank (2006), the Government should create a better business environment through labour policies and quality standards throughout the supply chain, though Große-Rüschkamp and Seelige (2010) say that it is not likely to happen soon.

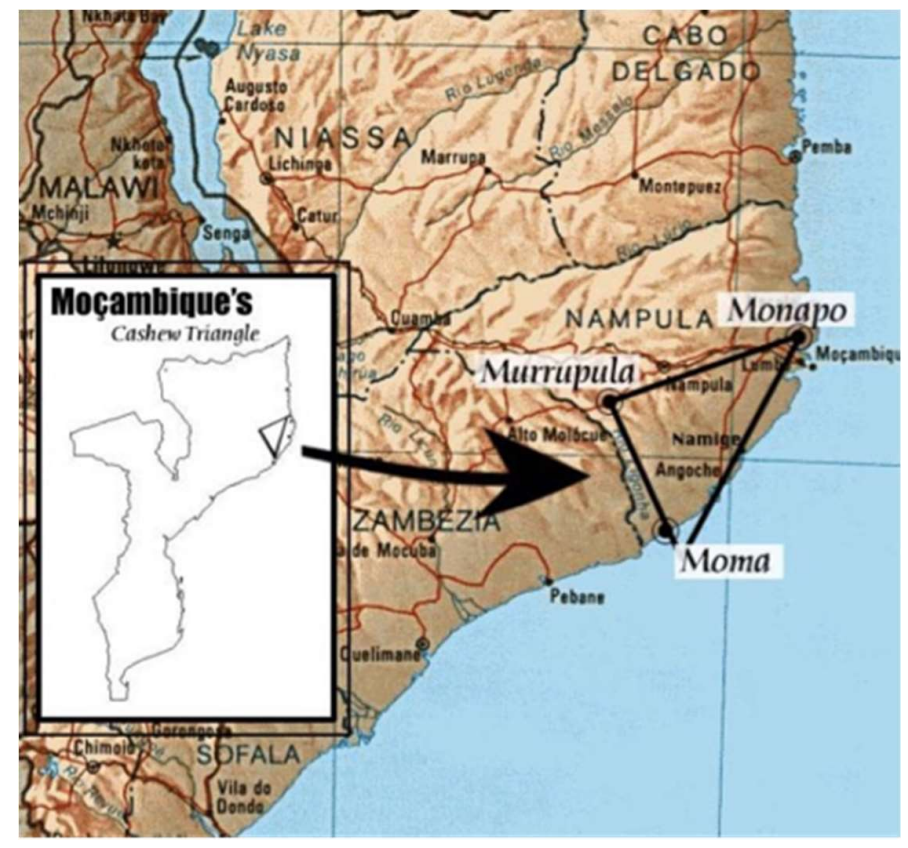

Figure 2. The "Cashew Triangle". Source: Paul [30].

\subsection{Peculiarity of Mozambican cashew nuts and its industry}

Cashew is native from Northeast Brazil (Baldeo 1995) and one must expect that most natural enemies are there. Without the current accurate tools to evaluate environmental impact and even with limited knowledge about Darwin's concept of natural selection, before the $19^{\text {th }}$ century, the introduction of a particular species in a new area would often produce quite unexpected outcomes. Such results were certainly desirable when the Portuguese traders took cashews to the northern Mozambican sandy coastal soils in the $16^{\text {th }}$ century (Kanji, Vijfhuizen, Artur, et al. 2004, McLaughlin, Balerdi, and Crane 2000, Kanji, Vijfhuizen, Braga, et al. 2004). According to MEDA (2011), Mozambique has an appropriated environment, soil and climate for to the production of cashew nuts. These evidences suggest that the Mozambican environment improved the yield and possibly the quality of the cashew nuts. The ideal natural conditions plus the tradition of about five centuries and a good management prior to the independence explain why Mozambique peaked in 1972, with 216,000 tonnes, as the World's leading exporter (Kanji, Vijfhuizen, Braga, et al. 2004, Cramer 1999). 
The Mozambican cashew nuts could be regarded as a symbol of social justice as the industry employs a large number of women compared to men (Kanji, Vijfhuizen, Artur, et al. 2004). In the "Cashew triangle", women represent $82 \%$ of the workforce (Paul 2008). Thus, any effort to improve Mozambican cashew production, including a good promotion through the an official geographic indication, is lined with Millennium Development Goals such as the reduction of poverty and promotion of gender equality and empowerment of women (AEGEE-Europe 2011, Kanji, Vijfhuizen, Artur, et al. 2004). So, the tradition of female engagement and its impact might be a significant asset for the overall "picture" of the uniqueness regarding the Mozambican cashew nuts.

\section{Legal outlook of GI protection in Mozambique}

\subsection{Major events}

According to the Cabinet Council (2007), the industrial and intellectual properties were regulated under the colonial Portuguese legislation, particularly the Code of Industrial Property approved by the Decree no. 30679 (24/08/1940) extended to the colony through the Ordinance no. 17043 (20/02/1959). Some basic principles about the intellectual properties were also specified under the Civil Code approved by the Decree-Law no. 47344 (25/11/1966) and extended to the overseas Ordinance no. 22869 (18/12/1967). However, after the independence, the Constitution of the new People's Republic (in 1975) did not promote private initiative and the Portuguese laws fell into obsolescence.

The Cabinet Council (2007) also stated that the second Constitution of the Republic of Mozambique (in 1990) opened the economy to private initiatives (article 97-c) and recognised the private properties (article 86), the freedom to entrepreneurship and national or foreign investment (articles 107 and 108). The $3^{\text {rd }}$ Constitution (2004) is basically the same but it also protects the intellectual property (article 94). Mozambique also joined WTO, WIPO and ARIPO (Cabinet Council 2007) and issued a Trade Policy Review (TPR) in 2001, harmonised with certain provisions of the TRIPS Agreement (WTO 2008).

Mozambique has specific legislation for GI in the Industrial Property Code, Decree 18/99 (04/05/1999) (Cabinet Council 1999), reviewed and integrated in the Decree 4/2006 (12/07) of the Cabinet Council (2007). In the document, geographic indication was defined as "geographic name of a country, city, region or localities of its territory, known as production, fabrication or extraction of a particular product or service providing". The chapter VI of the title II provides details such as the general principle to attribute GI, the rights conferred by the registration, regional demarcation, claims, refusals, duration, caducity and non-transferability.

Then, the Mozambican Cabinet Council described the GI protection as part of their Strategy for Intellectual Property 2008-2018 (Cabinet Council 2007). According to it, the Government planned to create incentives for particular commodities from each district and promote their diffusion, certifying local brands, denomination of origin or geographic indication. One year later, Soeiro, Grade, and de Deus (2008) published the Legal and Institutional Framework for the Protection and Registration of Geographical Indications in Mozambique to provide technical assistance to the newly created Industrial Property Institute in geographical indications.

Subsequently, USAID (2009) published the Assessment of Mozambique's Intellectual Property System. According to it, stakeholders should be more involved in the police making system and the geographical indications still need to be implemented. Furthermore, the report says that the public awareness has been low. Thus, media professionals and journalists should have a major role in the promotion of knowledge related to intellectual property including GI.

\subsection{The Decree 18/99 and the Mozambican cashew nuts}

Looking closely the Decree 18/99 (04/05/1999, title II, chapter VI) of the Industrial Property Code, the name of a country or a particular area must be chosen (article 137). Nampula, the province where 
the "Cashew triangle" is located, is a plausible option by its popularity and emphasis given in many studies, including the one conducted by Große-Rüschkamp and Seelige (2010) and financed by the Bill and Melinda Gates Foundation. However, a realistic approach assuming the country not as popular in the media worldwide as France, Egypt or even South Africa, and since the southern producers also play a significant part in the industry, it would be strategically wiser to consider Mozambique as a whole for geographic indication. Furthermore, there is a trademark "Made in Mozambique" (MIC 2006) already popular in the country and probably rising in popularity in the international market as most of the larger companies are using it. The geographic indication and this trademark would have the potential to boost each other.

Only local producers can use GIs (article 138). So far, once exported, there is no clear distinction between the cashews from Mozambique and any other country but it is known that the local cashews reach the Indian market and the latter country is the biggest worldwide exporter. How much of their cashew is originally from countries like Mozambique? How many brands owe their reputation to the unique values rising from the natural Mozambican cashews?

The clear definition of the area (article 139), as it was mentioned, would be either Mozambique or Nampula. If Nampula is chosen, other significant producers from the southern provinces such as Inhambane, Gaza or Maputo would be excluded or otherwise set as different GI and both situations seem economically disadvantageous if one considers that these all areas could be marketing together under the GI Mozambique. Under the article 140 (claims), Mozambique as GI for cashew nuts could be introduced and promoted by INCAJU, described by Große-Rüschkamp and Seelige (2010) as the public entity responsible for the policy making and promotion of the cashew industry. However, fulfilling the article 140-c, some aspects regarding the technological and social aspects should be reviewed before the definition of "Mozambican cashew nuts". The typical Mozambican cashew factories have women as at least four-fifths of the personnel and use the sit-down cutting machine (Paul 2008). It would be important to study cautiously if different profiles are to be accepted. Following the same line of thought, the article 141 says that registration will be refused if the GI (d) is deceptive regarding the nature and quality of the product or (e) favours an unfair competition.

\section{Other Mozambican products protectable through GIs}

Mozambique is rich in biodiversity, According to USAID (2008). In summary, there is a fertile heterogeneous Mozambican environment expanded from the sea and coastline to a multitude of tropical vegetation profiles from savannahs, mangroves and dense forests plus some of the biggest African rivers. One must expect several GI possibilities. Indeed, crossing data from EPAU (2012) and World Bank (2013), prawn and cashew nuts would be the most significant, but tobacco, sugar, cotton and timber should not be ignored. The World Bank (2006) recommended sugar and tea for cash crops. Though probably all these commodities are good candidates to be considered for GI protection, only tea (from agriculture) and prawns (from fishery) will be briefly described as examples.

\subsection{Guruè tea}

In Mozambique, tea is mostly produced in the Guruè, Milange, Namarrói, Lugela, Ile and AltoMolocuè are districts from the central Zambezia province (Duarte 2006, Mahave 2008). The region is called Alta Zambézia because it is made of a plateau surrounded by a mountain chain including Namule, the country's second highest peak (Branco 2011, Duarte 2006).

The crop (Camelia sinensis L. O. kuntze) was introduced in 1914 in Milange and then expanded to the other areas and Gurue rapidly became the leader considering the cropping area, labour, volume of production and productivity (Duarte 2006). According to Duarte (2006), the success came from its tropical humid climate (7.4\% humidity), with annual average precipitation of $1987.3 \mathrm{~mm}$ (abundant rain) and temperature between $15.7-28^{\circ} \mathrm{C}$, described by him as appropriated to tea growth.

The so-called "Guruè tea" is currently produced by five companies employing about 2994 to 5130 people (211 effectives), covering 7835 hectares and the production, in 2010 and 2011 were 3056 
and 2306 tonnes, respectively (Sousa 2011). Branco (2011) says that Guruè's tea used to be internationally famous and it was exported to Portugal, USA and UK.

\subsection{Prawns}

The big fishery industry can be justified by the fact that Mozambique is easiest access to the sea and main source of seafood for most Southern African countries, particularly Zambia, Zimbabwe and Malawi. As a coastal country, Mozambique is rich in fishery resources (both marine and freshwater) (FAO 2007) and fishing is both tradition and imported practice from the Portuguese colonists, also a coastal population. The World Bank (2013) statistics show that prawn has always been the main export commodity.

The richest area is called Banco de Sofala, and it is explored by artisanal, semi-industrial and industrial sectors (Munguambe 1995, Pinto 1999). There is a wide variety of species including Penaeus indicus, P. monodon, P. semisulcatus, P. japonicas, P. latisulcatus and Metanopenaeus monoceros among others (FAO 2007, Munguambe 1995). Since the fishery is mostly industrial and some prawns come even from sophisticated practices such as aquaculture (FAO 2007), quite standardized, studies should be taken to find some peculiarities before any claim of GI for prawns. The commodity has economic relevance, is popular and traditionally valuable but the current industry profile is not stressing its uniqueness.

\section{Conclusions}

Regarding the legal framework for the protection of GIs (Decree 18/99 of the Industrial Property Code), the Mozambican cashew nuts and probably other export commodities, such as tea and prawns, are suitable. Indeed, the historical reputation and the factual social justice are strengths to be stressed if the cashew nuts are to be protected under GI. And there are possibilities for cashew nuts, as it is produced in two distinct areas, though it would be advantageous to use the country's name. However, there are other regulations negatively impacting the industries potentially compromising the significance of benefits arising from the Decree 18/99. For example, the system of taxation for the cashew nuts should be reviewed and environmental issues might impact the prawns.

Despite of the considerably well-defined legal framework and the existence of the Industrial Property Institute or similar organisations, there is little momentum in the enforcement of the IP regulation and a systematic and transparent implementation process involving the industrial, academic, media and civil communities is lacking. An extensive assessment of the potentiality or outcomes of the IP system (including GIs) by sector is also missing. Disregarding the regulations, the evidences suggest that most work is being done independently by few apparently unrelated nongovernmental entities.

Conflicts of Interest: The author declare no conflict of interest.

\section{References}

AEGEE-Europe. 2011. The UN Development Goals - A Challenge for Today's Youth? Edited by M. G. Varrenti, S. R. Ramirez and G. Motroc, Beyond Europe Flagship. Brussels: AEGEE-Europe.

African Union Comission, and European Commission. 2011. "List of potential GIs and legal arrangements in Africa." Creating value through Geographical Indications: the power of origin, Kampala.

Allsopp, M., Johnston, and D. Stanillo. 2008. Challenging the Aquaculture Industry on Sustainability. Amsterdam: Greenpeace Research Laboratories, University of Exeter.

Andreas, C. 2011. "Vanilla from Madagascar." Workshop on Geographical Indications, Kampala.

Baldeo, I. 1995. "Cashew production in Grenada." Regional Meeting on Cashew Research and Development, Trinidad and Tobago.

Bertelsmann Stiftung. 2012. BTI 2012 - Mozambique Country Report. Gütersloh: Bertelsmann Stiftung.

Blakeney, M., T. Coulet, G. Mengistie, and M. T. Mahop. 2012. Extending the Protection of Geographical Indications: Case Studies of Agricultural Products in Africa: Earthscan (from Routledge).

Blakeney, Michael. 2012. Geographical Indications and TRIPS. In Research Paper. Perth: University of Western Australia-Faculty of Law. 
Branco, P. 2011. "The precious leaves of Gurue - travels along Mozambique’s 'tea route'." Club of Mozambique, $16 / 06$.

http://www.clubofmozambique.com/solutions1/sectionnews.php?secao=tourism\&id=24992\&tipo=0 ne.

Cabinet Council. 1999. "Decreto no18/99: Aprova o Código da Propriedade Industrial de Moçambique." Boletim da República I (17).

Cabinet Council. 2007. "Estratégia da Propriedade Intelectual 2008-2018." XXIII Sessão Ordinária do Conselho de Ministros.

CIA. 2013. "Mozambique." Central Intelligence Agency, accessed 13/06. https://www.cia.gov/library/publications/the-world-factbook/geos/mz.html.

CIDA. 2013. "Mozambique: facts at a glance." Canadian International Development Agency (CIDA), accessed 13/06. http://www.acdi-cida.gc.ca/acdi-cida/ACDI-CIDA.nsf/En/JUD-22211545-LVP.

Cramer, C. 1999. "Can Africa industrialize by processing primary commodities? The case of Mozambican cashew nuts." World Development 27 (7):1247-1266.

Duarte, R. 2006. "A Agro-Indústria do Chá na Alta-Zambézia no Período Pós-Independência (1975-1987)." Licenciatura, Departamento de História, Universidade Eduardo Mondlane (HT-215).

Encyclopædia Britannica. 2013. "Mozambique." Encyclopædia Britannica Inc., accessed 08/03/2013. http://www.britannica.com/EBchecked/topic/395363/Mozambique.

EPAU. 2012. Mozambique Quick Facts: Economic and Policy Analysis Unit. edited by UNDP Mozambique. Maputo: The Economic and Policy Analysis Unit (EPAU), UNDP Mozambique.

European Commission. 2012. "Creating value through Geographical Indications: the power of origin (Workshop on Geographical Indications, Kampala (Uganda), 10-11/11/2011)." European Commission, accessed 17/06. http://ec.europa.eu/agriculture/events/gi-africa-2011_en.htm.

Evans, G. E., and M. Blakeney. 2006. "The protection of geographical indications after DOHA: quo vadis?" Journal of International Economic Law 9 (3):575-614. doi: 10.1093/jiel/jg1016.

FAO. 2007. National Fishery Sector Overview: The Republic Of Mozambique. In Fishery Country Profile: Food and Agriculture Organization of the United Nations.

Gichovi, B. 2011. "The Kenyan experience with a special focus on Kenya coffee." Workshop on Geographical Indications, Kampala.

Greenpeace. 2013. "Greenpeace International Seafood Red list." Greenpeace International, accessed 16/06. http://www.greenpeace.org/international/en/campaigns/oceans/seafood/red-list-of-species/.

Große-Rüschkamp, A., and K. Seelige. 2010. Análise da Cadeia de Valor do Caju em Moçambique. Edited by P. Keller, Iniciativa Africana do Caju. Maputo: Deutsche Gesellschaft für Internationale Zusammenarbeit (GIZ) $\mathrm{GmbH}$.

INTIC. 2006. "Informação Geral sobre Moçambique." Instituto Nacional de Tecnologias de Informação e Comunicação (INTIC), accessed 13/06. http://www.portaldogoverno.gov.mz/Mozambique.

IPpro. 2008. TRIPS Agreement: An Overview. edited by IPpro Inc.

Kanji, N., C. Vijfhuizen, L. Artur, and C. Braga. 2004. "Liberalisation,Gender and Livelihoods: The Mozambique Cashew Nut Case Summary Report." XI World Congress of Rural Sociology, Trondheim.

Kanji, N., C. Vijfhuizen, C. Braga, and L. Artur. 2004. Cashing in on Cashew Nuts: Women Producers and Factory Workers in Mozambique. In Chains of Fortune: Linking Women Producers and Workers with Global Markets.

Mahave, M. J. J. 2008. "Características Físico-Químicas do Chá Preto (Camelia sinensis (L.) O. kuntze) Nacional." Licenciatura, Departamento de Química, Universidade Eduardo Mondlane.

McLaughlin, J., C. Balerdi, and J. Crane. 2000. The Cashew Apple (Anacardium occidentale) in Florida. In Urban Horticulture Publications, edited by Institute of Food and Agricultural Sciences. Gainesville: University of Florida.

McMillan, M., D. Rodrik, and K. H. Welch. 2002. When Economic Reform Goes Wrong: Cashews in Mozambique. In NBER Working Paper Series. Cambridge: National Bureau of Economic Research.

MEDA. 2011. Value Chain Finance Assessment of the Cashew Nuts Sector in the Province of Nampula, Mozambique. In African Cashew initiative ( $A C i)$, edited by Mennonite Economic Development Associates (MEDA). Waterloo: GIZ.

MIC. 2006. Regulamento Sobre os Critérios de Concessão do Direito de Uso da Marca "Orgulho Moçambicano. Made in Mozambique". edited by Ministério da Indústria e Comércio: Instituto Nacional de Tecnologias de Informação e Comunicação (INTIC).

Munguambe, F. 1995. "Estudo da Distribuição, Composição por Espécies e Determinação de Alguns Aspectos Biológicos das duas Principais Espécies de Camarão no Banco de Sofala - P. indicus e M. monoceros." Licenciatura, Departamento de Ciências Biológicas, Universidade Eduardo Mondlane (Bio 114). 
Paul, B. 2008. Factories in the Field: Rural Transformation and the Organization of Work in Mozambique's Cashew Triangle. Norwalk: TechnoServe.

Pinto, M.A. 1999. "Gear selectivity for three by-catch species in the shallow-water shrimp trawl fishery at the Sofala Bank, Mozambique." FAO, UNESCO and IODE, accessed 16/06. http://hdl.handle.net/1834/364

Reserve Bank of Australia. 2013. "Exchange Rates." accessed 13/06. http://www.rba.gov.au/statistics/frequency/exchange-rates.html.

Soeiro, A., R. Grade, and D. de Deus. 2008. Technical Assistance to the Industrial Property Institute in Geographical Indications: Legal and Institutional Framework for the Protection and Registration of Geographical Indications in Mozambique. Brussels: CESO.

Sousa, R. 2011. "Zambézia - Guruè: produção de chá cresce em mil toneladas." accessed 16/06. http://mocaweb.com/section-table/42-cultura-mocambicana/1193-zambezia--gurue-producao-decha-cresce-em-mil-toneladas.html.

UNDP. 2010. Report on the Millennium Development Goals: Republic of Mozambique. United Nations Development Programme (UNDP).

UNICEF. $2003 . \quad$ "Mozambique at glance." UNICEF. http://www.unicef.org/mozambique/overview 11146.html.

USAID. 2008. Mozambique Biodiversity and Tropical Forests 118/119 Assessment. edited by Chemonics International Inc.: United States Agency for International Development (USAID).

USAID. 2009. An Assessment of Mozambique's Intellectual Property System. edited by Nathan Associates Inc.: United States Agency for International Development (USAID).

Welch, K. H. 2003. Liberalization of the Mozambican Cashew Industry. Kennedy School.

World Bank. 2006. Mozambique Agricultural Development Strategy: Stimulating Smallholder Agricultural Growth. World Bank.

World Bank. 2013. Mozambique at a glance. In Development Economics: LDB database.

WTO. 1994. Agreement on Trade Related Aspects of Intellectual Property Rights. edited by World Trade Organization (WTO): World Trade Organization (WTO).

WTO. 2008. Trade Policy Review: Report by the Secretariat. In Trade Policies and Practices by Measure: World Trade Organization. 